\title{
探索中国山地植物多样性的分布规律
}

\begin{abstract}
方精云
( 北京大学环境学院生态学系, 北京大学生态学研究与教育中心 北京大学地表过程分析与模拟教育部重点实验室, 北京 100871)
\end{abstract}

\section{Exploring altitudinal patterns of plant diversity of China's mountains}

\author{
FANG Jing-Yun \\ Department of Ecology, College of Environmental Sciences , Center for Ecological Research \& Education, \\ and Key Laboratory for Earth Surface Processes of the Ministry of Education, Peking University , Beijing \\ 100871
}

目前地球上的生物物种每年以 $0.1 \%-1.1 \%$ 的速率在急剧减少 (World Conservation Monitoring Centre，1992），人类社会开始进入保护生物多样性 的时代。大规模开唇土地导致的自然生境快速丧失 是生物多样性急剧减少的根本原因。山地由于具有 浓缩的环境梯度和高度异质化的生境、相对较低的 人类干扰强度, 以及在地质历史上常成为大量物种 的避难所和新兴植物区系分化繁衍的摇篮，所以发 育和保存着较高的生物多样性, 成为全球生物多样 性研究和保护的重点区域(Messerli \& Ives , 1997 ; Körnor ,2000 ; Myers et al. ,2000)。

我国是一个多山的国家，山地面积约占国土总 面积的 2/3 (中国科学院《中国自然地理》编委会, $1985)$ 。这些由新华夏构造体系和喜马拉雅运动形 成的山脉体系，包括多列近南北走向 (如横断山脉、 贺兰山脉) 、北东走向 (大兴安岭一燕山一吕梁山一 巫山一武陵山脉, 长白山, 浙闽丘陵等) 和近东西走 向的山脉 (如阴山一天山、昆仑山一秦岭、南岭等)， 排列有序 构成了我国宏观地形的基本骨架 (任美 锷，1982)。它们不仅反映和浓缩了水平地带性的 自然地理特点和生物地理特征, 成为验证和发展有 关物种多样性理论的理想场所, 也由于受人类活动 的影响较小而富含生物多样性资源, 成为我国可持 续发展的重要生物资源保障( 方精云等 2004a)。

围绕中国山地的生物多样性研究, 国内外已有 大量报道。如，Mackinnon et al. (1996) 综述了中国
不同区域的生物多样性背景信息，陈昌笃等(1997) 归纳和分析了我国各自然区域和主要生物类群的生 物多样性特征，陈灵芝等 (1997) 总结了我国森林群 落多样性及其分布特点, 刘世荣和蒋有绪 (1998)、 高贤明等 (2001) 对我国暖温带森林生物多样性进 行了研究 蒋有绪等 (2002) 探讨了海南岛的生物多 样性格局及其形成机制。此外, 还有不少山地生物 多样性的案例研究( 简焯坡等, 1975; 应俊生等, 1979 ; 马克平等,1995; 沈泽昊等,2000; 王国宏， 2002 ; 郝占庆等 2002)。这些研究为开展我国山地 生物多样性的大规模调查积累了宝贵资料。然而, 这些工作多针对某一区域或某一山地, 而且不同作 者在研究不同山地时, 往往采用不同的技术规范, 因 此, 不同研究结果之间难以比较。为此, 基于统一的 方法和技术规范, 开展我国山地物种多样性的大规 模调查显得十分必要。

自 20 世纪 90 年代中期开始, 北京大学陆地生 态系统研究小组在北京大学 中国山地植物物种多 样性调查计划” ( PKU-PSD 计划) (方精云等, $2004 b$ ) 的框架下, 开展了我国山地植物多样性的系 统调查。该计划在国家有关部门、北京大学以及国 内广大同仁的大力支持和协助下 到目前为止, 已完 成了我国东部主要山地的调查, 中西部山地的野外 调查工作预计也将于两年后完成。

十多年来, 课题组成员踏遍了祖国的山山水水， 经历过不止一次的翻车惊险, 感受过不止一回的迷 


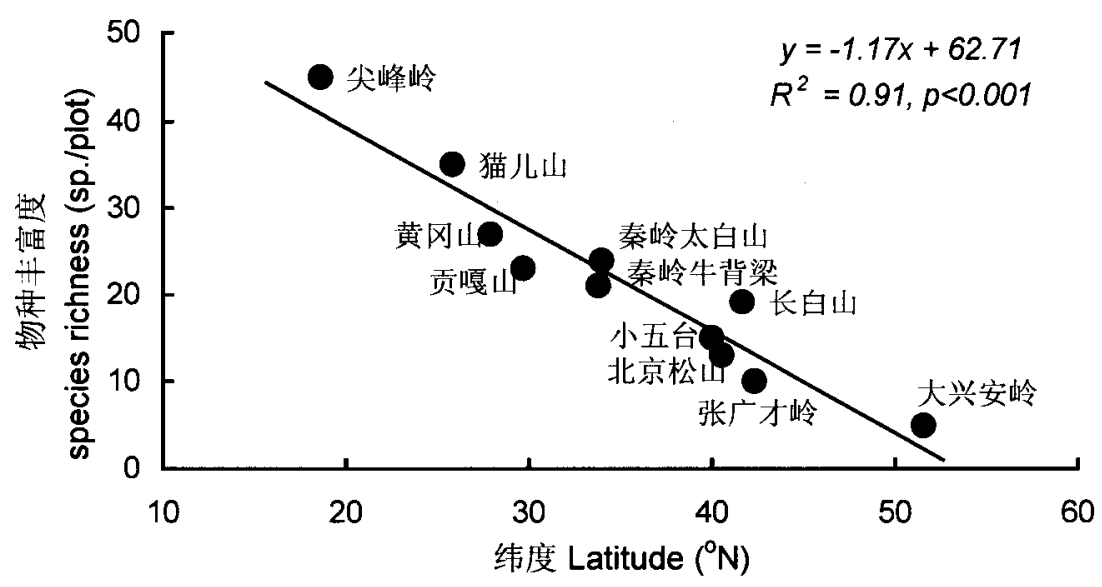

图 1 我国东部主要山地木本植物物种丰富度与纬度的关系。物种丰富度为各山地调查样方的平均值。样方的海拔范围为 $800-1400 \mathrm{~m}$ 样方面积为 $400-600 \mathrm{~m}^{2} / \mathrm{plot}^{\circ}$ 数据来自本期的有关文章。

Fig. 1 Relationship between woody species richness and latitude for 11 mountains of Eastern China. The value of species richness is averaged over plots ( $400-600 \mathrm{~m}^{2} /$ plot , $800-1400 \mathrm{~m}$ a. s. l. ) for each mountain. All data are from relevant papers in this issue.

路于茾莽森林的恐惧, 更忍受过因高原缺氧数日在 急救室中作生死挣扎的痛苦。然而, 令人欣慰的是, 大家的努力换来了大量的第一手资料。本专辑就是 对这些资料的初步分析和总结。希望本专辑的出版 能帮助读者了解我国主要山地植物群落及物种多样 性的概貌, 并为开展更深入的研究和综合分析提供 基础数据。同时希望本专辑的出版也能引起人们对 野外数据采集的进一步重视。生态学又常常被称为 野外生物学 (field biology) (Smith，1990)，说明野外 工作对生态学科的重要性。希望国内的生态学研究 能够像 20 世纪五六十年代那样, 更加重视野外实地 调查工作。

本专辑由 6 部分组成, 共收录文章 24 篇。第一 部分收录 3 篇文章, 主要介绍 PKU-PSD 计划的主要 内容和主要技术规范, 提出山地生态学的研究框架, 综述国内外山地物种多样性的研究进展。第二部分 收录 8 篇文章, 主要报告我国热带和亚热带山地植 物多样性的调查结果。第三部分由 7 篇文章组成, 主要反映我国暖温带山地植物群落多样性及结构特 征。第四部分由 3 篇文章组成, 主要分析我国东北 地区 (温带和寒温带) 若干山地的群落结构和多样 性特征随海拔的变化趋势。第五部分的 2 篇文章探 讨了青藏高原高寒植物群落的物种多样性及其与环 境因子的关系。最后部分提供了我国主要山地及山 峰的基本地理信息, 以便为以后的类似研究提供背
景资料。

根据上述论文, 可以初步归纳出我国山地植物 物种多样性分布的 3 个基本特点:

(1) 在人为干扰较少的山地，木本植物多样性 分布的一般规律是随海拔升高, 物种丰富度 (species richness) 逐渐减少，符合扩展的 Rapoport 法则( Rapoport's Rule) ( Stevens , 1992)。但在一些山地, 物 种丰富度随海拔的升高呈单峰分布格局, 即在中海 拔地段丰富度最大, 如高黎贡山(王志恒等, 2004)。 这种格局可能与低海拔地区受人为干扰较强, 而高 海拔山地的面积较小等因素有关。

(2) 我国植物的物种丰富度或物种密度 (species density) 自南向北逐渐减少, 符合 Rapoport 的纬 度法则 (Rapoport's Latitudinal Rule) ( Stevens， 1992 )。图 1 为我国东部 11 个受人类干扰较少的山 地木本植物的物种丰富度与纬度的关系。该图所使 用的数据基本来自相似的海拔高度 $(800-1400$ $\mathrm{m})$ 样方面积也基本相同 $\left(400-600 \mathrm{~m}^{2} / \mathrm{plot}\right)$ 。可 以看出, 随纬度的增加, 物种丰富度显著减少; 纬度 每增加一度, 物种数约减少 1.2 种。

(3) 不同生活型的植物, 其物种多样性随海拔 高度的变化趋势不尽相同。草本植物的物种丰富度 主要受乔木层郁闭度的影响, 而与海拔的关系不明 显。 
致谢: PKU-PSD 计划是在国家自然科学基金委员 会、国家科技部、国家教育部和北京大学等部门多个 项目的支持下实施的，先后得到国家自然科学基金 委的国家杰出青年科学基金 (39425003)、创新群体 试点基金 (40024101)、重点基金 (39830050)、面上 基金(39470132、39970044、49971002、30000024），国 家科技部的国家重点基础研究发展计划 (G2000046801) 和国家科技攻关项目 (85-913-0102 )、教育部重点科技项目 (99001)、北京大学 211 工程”及 985 计划”的资助。在此, 谨向上述部门致 以诚挚谢意。在各地调查中，我们得到了当地广大 科研人员的协助。特别感谢黄全 (海南)、刘初钿 (福建)、李光照 (广西、湖南)、王跃华、何家卫(云 南)、吴鸣翔 (浙江)、方嗣昭 (贵州)、李锡文、周浙 昆、郎楷永、方江平等 (西藏)、杨一团 (湖南)、赵子 恩 (湖北)、贺家仁 (四川)、李智军、吴振海 (陕西)、 龚湧 (河北)、王权业 (青海)、崔海亭 (北京、内蒙)、 宗占江、王政权 (东北地区) 等先生在野外调查和植 物鉴定等方面所给予的大力支持。我们的野外工作 也得到了大量临时人员的帮助，这里虽不能一一列 出姓名, 仍应同样致谢。特别感谢李振宇先生花费 大量宝贵时间审核了本专辑的全部植物学名。匿名 审稿人的建设性意见对提高本专辑的学术质量帮助 甚大，《生物多样性》编辑部的孙大川、时意专和间 文杰女士, 主编汪小全先生为本专辑的出版付出了 大量艰辛劳动, 这里谨致谢忱。最后, 我们愿将这一 专辑特别献给为调查我国山地植物资源贡献毕生精 力的老一辈科学家和正在辛勤劳作的第一线科技工 作者, 尤其是长年生活和工作在环境极为恶劣的边 远山区的植物学工作者们。

\section{参考文献}

Chen, C. D. (陈昌笃) ( ed.). 1997. China's Biodiversity: A Country Study(中国生物多样性国情研究报告). China Environmental Science Press, Beijing. (in Chinese)

Chen, L. Z. (陈灵芝), Chen, Q. L. (陈清朗) and Liu, W. H. (刘文华). 1997. Forest Diversity and Its Geographical Distribution in China (中国森林多样性及其地理分布).

Science Press, Beijing. (in Chinese)

Editorial Committee for Physical Geography of China, CAS (中 科院《中国自然地理》编委会) . 1985. Physical Geography of China: A General Summary. (中国自然地理一总论)

Science Press, Beijing. (in Chinese)
Fang, J. Y. (方精云), Shen, Z. H. (沈泽昊) and Cui, H. T. (崔海亭). 2004a. Ecological characteristics of mountains and research issues of mountain ecology. Biodiversity Science (生物多样性)，12(1)：10 - 19. (in Chinese)

Fang, J. Y. (方精云), Shen, Z. H. (沈泽昊), Tang, Z. Y. (唐志尧) and Wang, Z. H. (王志恒). 2004b. The Protocol for the Survey Plan for Plant Species Diversity of China's Mountains. Biodiversity Science (生物多样性), 12 (1) : 5-9. (in Chinese)

Gao, X. M. (高贤明), Ma, K. P. (马克平) and Chen, L. Z. (陈灵芝). 2001. Species diversity of some deciduous broad-leaved forests in the warm-temperate zone and its relations to community stability. Acta Phytoecologica Sinica (植物生态学报), 25: 283 -290. (in Chinese)

Hao, Z. Q. (郝占庆), Yu, D. Y. (于德永), Yang, X. M. (杨晓明) and Ding, Z. H. (丁之惠). 2002. $\alpha$-diversity of communities and their variety along altitude gradient on northern slope of Changbai Mountain. Chinese Journal of Applied Ecology (应用生态学报), 13 (7): 785 - 789. ( in Chinese)

Jiang, Y. X. (蒋有绪), Wang, B. S. (王伯荪), Zang, R. G. (藏润国), Jin, J. H. (金建华) and Liao, W. B. (廖文波). 2002. Biodiversity and Its Mechanisms of Tropical Forests in Hainan Island (海南岛热带雨林的生物多样 性及机制). Science Press, Beijing. (in Chinese)

Körnor, C. 2000. Why are there global gradients in species richness? Mountains might hold the answer. TREE, 15: $513-514$.

Liu, S. R. (刘世荣) and Jiang Y. S. (蒋有绪). 1998.A Study on the Biodiversity in Warm Temperate Forest in Chi$n a$ (我国暖温带森林生物多样性的研究). China Science and Technology Press, Beijing. (in Chinese)

Ma, K. P. (马克平), Huang, J. H. (黄建辉), Yu, S. L. (于顺利) and Chen, L. Z. (陈灵芝) . 1995. Plant community diversity in Dongling Mountain, Beijing, China: II. Species richness, evenness and species diversities. Acta Ecologica Sinica (生态学报), 15: 268 - 277. (in Chinese)

Mackinnon, J., Sha, M., Cheung, C., Carey, G., Zhu, X. and Melville, D. 1996. A Biodiversity Review of China. WWF International, Hong Kong.

Messerli, B. and Ives, J. D. 1997. Mountains of the World: A Global Priority. The Parthenon Publishing Group, New York.

Myers, N., Mittermeier, R. A., Mittermeier C. G., da Fonseca G. A. B. and Kent J. 2000. Biodiversity hotspots for conservation priorities. Nature, 403: $853-858$.

Ren, M. E. (任美锷). 1982. Outline of China's Physical Ge- 
ography(中国自然地理纲要). Business Press, Beijing. ( in Chinese)

Shen, Z. H. (沈泽昊), Zhang, X. S. (张新时) and Jin, Y. X. (金义兴). 2000. Spatial pattern analysis and topographical interpretation of species diversity in the forests of Dalaoling in the Three Gorges Region. Acta Botanica Sinica (植物学报), 42: 620-627. (in Chinese)

Smith, R. L. 1990. Ecology and Field Biology (4th edition). HarperCollins Publishers, New York.

Stevens, G. C. 1992. The elevational gradient in altitudinal range: an extension of Rapoport's latitudinal rule to altitude. American Naturalist, 140: 893 -911.

Tsien, C. P. (简焯坡), Ying, T. S. (应俊生), Ma, C. G. (马成功), Li, Y. R. (李雅茹), Chang, C. S. (张志 松) and Min, T. L. (闵天禄). 1975. The distribution of beech forests of Mt. Fanjingshan and its significance in plant geography. Acta Phytotaxonomica Sinica (植物分类 学报), 13: 5 - 18. ( in Chinese)
Wang, G. H. (王国宏). 2002. Species diversity of plant communities along altitudinal gradient in the middle section of north slopes of Qilian Mountains, Zhangye, Gansu, China. Biodiversity Science (生物多样性), 10(1)：7-14. (in Chinese)

Wang, Z. H. (王志恒), Chen, A. P. (陈安平), Piao, S. L. (朴世龙) and Fang, J. Y. (方精云). 2004. Pattern of species richness along an altitudinal gradient in Mt. Gaoligong, Southwest China. Biodiversity Science (生物多样 性), 12(1) : 82-88. (in Chinese)

World Conservation Monitoring Centre. 1992. Global Biodiversity: Status of the Earth's Living Resource. Chapman \& Hall, London.

Ying, T. S. (应俊生), Ma, C. G. (马成功), Chang, Z. S. (张志松). 1979. Observations of the flora and vegetation of Mt. Shennongjia in western Hupeh, China. Acta Phytotaxonomica Sinica (植物分类学报), 17(3)：41-59. (in Chinese) 